\title{
LABORATORY INFECTION OF THE WILD RODENT, SCIURUS ALPHONSEI WITH PASTEURELLA PESTIS
}

\author{
Dalva $A$. de Mello
}

The author studied the susceptibility of the wild rodent, Sciurus alphonsei (Sciuridae) from Brazil to Pasteurella pestis.

Two strains of $\mathrm{P}$. pestis isolated from wild rodents were used: one, $P$. EXU 19, was isolated from $O$. subflavus in the county of Exu, Pernambuco (Brazil), and other, RANGEL, isolated from S. hispidus of Camp. Rangel (Venezuela) .

Six animals were tested by inoculation through different routes (percutaneous, subcutaneous and peritoneal).

All the animals died as a result of the infection.

Several species of the rodent family Sciuridae have been found naturally infected with $P$. pestis. That family ranks as the second in importance in relation to epidemiology of plague (C.M.S. 1959).

In Mongolia, Manchuria, Transbaikalia, and Russia Turkestan the Sciuridae genus Marmota is considered the main plague resevoir while the genus Citellus plays the same role in the south-east Russia northen foci. Citellus and Cynomys are important reservoir hosts in the USA western states (Arizona and New Mexico) as well as in the coastal regions and northern part of intermountain plateau. In South America, Sciurus stramineus nebouxi is the main reservoir in the Peru/Equador border region (6) .

Although species of Brazilian squirrels (family Sciuridae) had never been incriminated as reservoir hosts of plague in Brazil, the genus Sciurus has large geographical distribution in forest regions of this country (4).
Sciurus alphonsei Thomas, 1906 was recorded from plague endemic areas by the former "National Service of Plague" in the state of Alagoas, county of Viçosa (1), Silva and Valença, (8), recorded species of the family Sciuridae in the state of Ceara.

It should be added that plague is known to occur in Brazil in forest as well as in semi-arid ("caatinga") regions.

According to the views above expressed the author decided to test the laboratory susceptibility of Sciurus alphonsei to two strains of Pasteurella pestis.

\section{MATERIAL AND METHODS}

The experiments were conducted in the period of October 1967 to March 1968.

Six specimens of Sciurus alphonsei were utilized for the inoculation experiments. The animals belonging to both sexes and different origins, were kept in laboratory

- Instituto Nacional de Endemias Rurais - Centro de Pesqui sas Aggeu Magalhães' Recifo - Brasil This work was supported in part by a Grant from SUD ENE for research on Plague in Northeastern Recife, Brazil. 
T A B L E I

Results of the inoculations of the Brazilian squirrel, Sciurus alphonsei, with Pasteurella pestis October 1967 - March 1968

Recife - Brazil

\begin{tabular}{|c|c|c|c|c|c|c|c|}
\hline \multicolumn{3}{|c|}{ A N I MA I S } & \multirow{2}{*}{$P$ strain $_{\text {pestis }}$} & \multirow{2}{*}{$\begin{array}{l}\text { Inoculation } \\
\text { route }\end{array}$} & \multicolumn{3}{|c|}{$R E S U L T S$} \\
\hline Grigin and sex & & Reference & & & $\begin{array}{c}\text { Survival } \\
\text { Period } \\
\text { (days) }\end{array}$ & $\begin{array}{l}\text { Direct } \\
\text { smears }\end{array}$ & CULTIVATION \\
\hline $\begin{array}{l}\text { Recife - Pe. } \\
\text { São Lourenço - Pe. } \\
\text { Serra Branca - Ma. } \\
\text { Carolina - Pi. } \\
\text { Carolina - Pi. } \\
\text { Carolina - Pi. }\end{array}$ & $\begin{array}{l}\sigma^{7} \\
\sigma^{7} \\
q \\
0 \\
0^{x} \\
\sigma^{x}\end{array}$ & $\begin{array}{ll}\text { Animal } & \mathbf{A} \\
\text { Animal } & \mathbf{B} \\
\text { Animal } & \mathbf{C} \\
\text { Animal } & \mathbf{D} \\
\text { Animal } & \mathbf{E} \\
\text { Animal } & \mathbf{F}\end{array}$ & $\begin{array}{l}\text { P. EXÚ } 19 \\
\text { RANGEL } \\
\text { RANGEL } \\
\text { P. EXÚ } 19 \\
\text { RANGEL } \\
\text { P. EXÚ } 19\end{array}$ & $\begin{array}{l}\text { Percutaneous } \\
\text { Percutaneous } \\
\text { Subcutaneous } \\
\text { Subcutaneous } \\
\text { Peritoneal } \\
\text { Peritoneal }\end{array}$ & $\begin{array}{l}2 \\
4 \\
6 \\
6 \\
4 \\
4\end{array}$ & $\begin{array}{l}\text { Positive } \\
\text { Positive } \\
\text { Positive } \\
\text { Positive } \\
\text { Positive } \\
\text { Positive }\end{array}$ & $\begin{array}{l}\text { Negative } \\
\text { Negative } \\
\text { Positive } \\
\text { Positive } \\
\text { Positive } \\
\text { Positive }\end{array}$ \\
\hline
\end{tabular}

$\bullet$ 
for a minimum of two weeks before the inoculations.

The animals were autopsied and inspected for macroscopic lesions. Liver, spleen, and lungs were fixed in Boiun's fluid and sections stained with hematoxilin-eosin to study microscopic lesions. Direct smears and inoculations in Petri dishes were made from blood, lung, liver, spleen and peritoneal fluid when present.

Two strains of $P$. pestis were used for the inoculations. The first, called P. EXU 19, had been isolated from a wild rodent, O. subflavus, in the county of Exu, State of Pernambuco (Brazil), the second one, known as RANGEL, was obtained from Camp. Rangel (Venezuela) and had been isolated from the wild rodent $S$. hispidus.

Before inoculations, $P$. pestis cultures were incubated at $36^{\circ} \mathrm{C}$ in peptone water for 24 hours.

Inoculations were made by percutaneous, subcutaneous or peritoneal routes. The percutaneous inoculations were made on the dorsal surface of the animals over an area of $2 \mathrm{sq}$ cent where the hairs had been pulled by hand. Subcutaneous inoculations were made through the skin of the inner surface of the thigh. For peritoneal inoculation, the liquid was introduced through the skin of the ventral surface of the animal. For all routes the amount of the inoculum was $0.2 \mathrm{ml}$ of a 24 hours peptone water media corresponding to $1,612,000$ germs.

\section{RESULTS}

Table I shows the results obtained from the six animals experimentaly infected with $P$. pestis.

Animal A was found dead after 48 hours of percutaneous infection. On the inoculation surface no specific lesion had developed. Smears from liver, spleen, lungs and heart blood showed bipolar gram negative bacilli. However, cultivation of those organs on nutrient agar did not show any growth. Microscopic pathology showed the following lesions: Lung - congestion of the capillary vessels, focal hemorrhagic areas where large amount of minute brownish pigment granules were seen, slight cellular infiltration of lympho - histiocytic tipe; Liver - congestion of blood portal vessels, rare necrosis foci of the parenchyma, slight hyperplasia of Küpfer cells in which fine brownish granules were seen in the cytoplasm.

Animal B, inoculated with Rangel strain by percutaneous route, showed typical cutaneous lesions in the third day after inoculation. Next day the animal was found dead. Bipolar bacilli were found in smears of liver, spleen, lungs and blood, but cultivation of that organs on nutrient agar gave negative results. A pool made from the squirrel's organs was scrubbed on the back of the depilated skin of a guinea-pig. At the third day this animal presented typical pustules on the inoculation site. The guinea-pig was sacrificed on the 5th day and although lesions were not apparent at the autopsy, plague bacilli were reisolated from the animal organs. The same microscopic lesions described for animal $\mathbf{A}$ were seen in animal $\mathbf{B}$, except that in the liver the lesions were more advanced and areas of fragmentation of the trabecula were observed. Lymphoreticular hyperplasia was found in the spleen.

Animal $\mathrm{C}$ and $\mathrm{D}$ were inoculated by subcutaneous route. The first one was found dead six days after the inoculation with Rangel strain. The autopsy showed a hypertrophic liver beset with whitish minute points: spleen - hypertrophic with necrosis areas; Lung - with hemorrhagic points. Numerous bipolar gram-negative bacilli were found in blood, liver and lungs smears. $P$. pestis bacilli were recovered from all the animal organs.

Microscopic lesions in animal $C$ were as follows: Lung - congestion, oedema, marked and difuse cellular infiltration (histiocytes and lymphocytes) and areas of micro-abcesses; Liver - congestion, sub-capsular hemorrhagic areas, slight lympho-histiocytic infiltration, limited areas of focal parenchymal necrosis, hyperplasia of the Küpfer cells; Spleen - congestion, Impho-reticular hyperplasia and numerous hemorrhagic areas.

Animal D, which had been infected with the strain P. EXU 19, was found dead 4 days after the inoculation. Liver was hypertrophic and studded with pin-head size whitish granules; spleen was volumous and showed necrosis areas, and lungs were congested. Direct smears from that organs and subsequent cultivations produced $P$. 
pestis bacilli. Microscopic pathology showed the following lesions: Liver - atrophic, with extensive parenchymal areas of necrosis, hepatic cells showing cloudy swelling: Spleen - extensive lymphoreticular hyperplasia, large amount of brown-yellowish pigment and minute granules.

Animal $\mathbf{E}$ and $\mathbf{F}$ were infected by peritoneal route by using strains RANGEL and P. EXU 19 respectively. Both animals were found dead on in the fourth day after the inoculations.

Animal E presented at autopsy an enlarged liver, but lungs and spleen showed normal appearence. Smears and cultivations from the animal organs and blood yielded plague bacilli. The following microscopic lesions were recorded: Lung - congestion of the blood capilary vessels, lympho-histiocytic cellular infiltration; Liver - congestion of the portal vessels, parenchyma showing rather extensive areas of atrophy and opaque degeneration of the hepatocytes; Spleen - moderate lymphoreticular hyperplasia.

Gross lesions presented by animal $F$ were: volumous liver studded with whitish minute granules and necrosis foci; spleen enlarged and peritoneal effusion. Plague bacilli were seen and isolated from spleen, lungs, liver, peritoneal fluid and blood. This animal presented the following microscopic lesions; Lungs - congestion and extensive parenchymal areas of oedema and lympho-histiocytic infiltration; Liver - congestion of the blood vessels, numerous parenchymal areas of focal necrosis, hepatocytes showing signs of atrophy or opaque degeneration, hyperplasia of the
Küpfer cells; Spleen - parenchymal focal areas of hemorrhage, lymphoreticular hyperplasia, oedema and distention of the sinusoids under the capsule, exudate composed of polynuclear and mononuclear white cells and fibrine.

\section{COMMENTS AND CONCLUSIONS}

All the six animals used in the experiments were positive to infection with two strains of Pasteurella pestis.

The animals died between 2 and 6 days after the infection with the same inoculum. In 66,6 per cent of the cases, plague bacilli was recovered from the infected animals.

Gross and microscopic pathology showed extensive lesions caused by plague bacilli. Similar lesions were found by Simon (3), and by Silva (7) in other wild rodents experimentally infected.

In USA, Holdendried and Quan (2) demonstrated that three species of Cittelus (Sciuridae) from New Mexico were moderatelly resistant to plague infection.

Ground-squirrels (Cittelus) from Cal1fornia were experimentally infected by Meyer (3), who concluded that young specimens were more susceptible than adults, males more susceptible than females, and animals from endemic areas more resistant than those from non-endemic areas.

Although, in the current paper, quantitative estimation of the lethal doses was not attempted, results presented indicate that the Brazilian squirrel, Sciurus alphon$s e i$ can he readily infected with $P$. pestis.

\section{RESUMO}

o autor estudou a susceptibilidade à Pasteurella pestis de um roedor silvestre encontrado no Brasil, Sciurus alphonsei (sciuridae).

Foram utilizadas duas cêpas de $\mathrm{P}$ pestis procedentes de roedores silvestres: uma, $P$. EXU 19, isolada de O. subflavus no municipio de Exu, Pernambuco (Brasil) e a outra, RANGEL, isolada de $\mathrm{S}$. hispidus de Camp. Rangel (Venezuela) .

Foram testados seis animais inoculados por diferentes vias (percutânea, subcutânea e peritoneal).

Todos os animais morreram com resultados positivos à infecção. 


\section{ACKNOWLEDGMENT}

Thanks are due to Dr. Aggeu Magalhäes Filho who was very kind in studying the microscopic lesions presented by the infected animals.

\section{REFERENCES}

1 - BUARQUE LIMA - Personal information, 1967.

2 - HOLDENDRIED, $R$. and QUAN, F. S. - Susceptibility of New Mexico Rodents to Experimental Plague. Pub. Health Rep. 71: 979-984, 1956.

3 - MEYER, K.F. - 1942. In Holdendried, R. and Quan, F.S. - Susceptibility of New Mexico Rodents to Experimental Plague. Pub. Health Rep. 71: 979, 1956.

4 - MCOJEN, JOÃO - OS roedores do Brasil. Instituto Nacional do Livro. Biblioteca Cientifica Brasileira. Série A - II. Rio de Janeiro, 1952.

5 - O.M.S. - Expert Commitee on Plague. Third Report. Wolrd Health Organization - Technical Report Series n.o 16, Palais de Nations Geneva, 1959.
6 - POLLITZER, R. - Plague World Health Organization: Monograph Series n. ${ }^{\circ} 22$. Palais des Nations Geneva, 1954

7 - SILVA, JR., - Peste e seu diagnóstico no homem e nos roedores - Separata do "Arquivos de Higiene", dezembro, 1941.

8 - SILVA, JR., \& VALENÇA JR., V.V. - Atividades do laboratório de peste da Delegacia Federal de Saúde da antiga $3 .^{\mathrm{a}}$ Região, com sede em Fortaleza, O Hospital 19: 957-92, 1941.

9 - SIMON, R. - Verificação da sensibilidade dos roedores da região Neotrópica - Monografias do Serviço Nacional de Peste. Gráfica Debret. Rio de Janeiro - Brasil, 1951. 


\section{REGULAMENTO DO PREMIO GERHARD DOMAGK}

Art. $1^{\circ}$ - O prêmio Gerhard Domagk é cferecido anualmente a partir de 1963, pela A CHIMICA "BAYER" S.A. em comemoração do centenário da fundação da FARBENFABRIKEN BAYER AG., de Leverkusen, Alemanha, ao autor ou autôres do melhor trabalho sôbre temas de medicina tropical (Doenças Infectuosas e Parasitárias, de Nutrição, Fisiologia e Higiene Tropicais), uma vez que o mesmo satisfaça às exigências dêste Regulamento.

Art. $20^{\circ}$ - Concorrerão ao referido prêmio todos os trabalhos publicados na REVISTA DA SOCIEDADE BRASILEIRA DE MEDICINA TROPICAL durante $O$ ano anterior.

Art. $3 .^{\circ}$ - O prêmio constará de uma importância em dinheiro, estipulada anualmente, e de uma medalha com o respectivo diploma assinado pelo Presidente e Secretário-Geral da Sociedade. No caso de trabalho em colaboração, o prêmio em dinheiro será conferido à equipe, porém cada um dos co-autores receberá uma medalha e um diploma, que mencionará ser o prêmio pertencente à equipe.
Art. $4 .^{\circ}$ - Serão membros da Comissão Julgadora o Presidente da Sociedade Brasileira de Medicina Tropical, que a presidirá, e os integrantes do Conselho Consultivo da REVISTA DA SOCIEDADE BRASILEIRA DE MEDICINA TROPICAL.

Art. 5. - Cada membro da Comissão Julgadora indicará os 5 melhores trabalhos publicados durante $o$ ano, sendo premiado aquêle que obtiver maior número de votos. Caberá ao Presidente da Sociedade Brasileira de Medicina Tropical a decisão final em caso de empate.

Art. $60^{\circ}$ - A Comissão Julgadora deverá emitir seu parecer até a data do início do Congresso anual da Sociedade Brasileira de Medicina Tropical, quando o prêmio será entregue em sessão solene.

Art. 7. - Não caberá qualquer recurso ao parecer da Comissão Julgadora.

Art. $80^{\circ}-$ O Presidente da Sociedade Brasileira de Medicina Tropical será árbitro supremo para decidir as dúvidas surgidas na interpretação dêste Regulamento ou resolver qualquer dificuldade em sua execução.

ERRATA DO AUTOR:

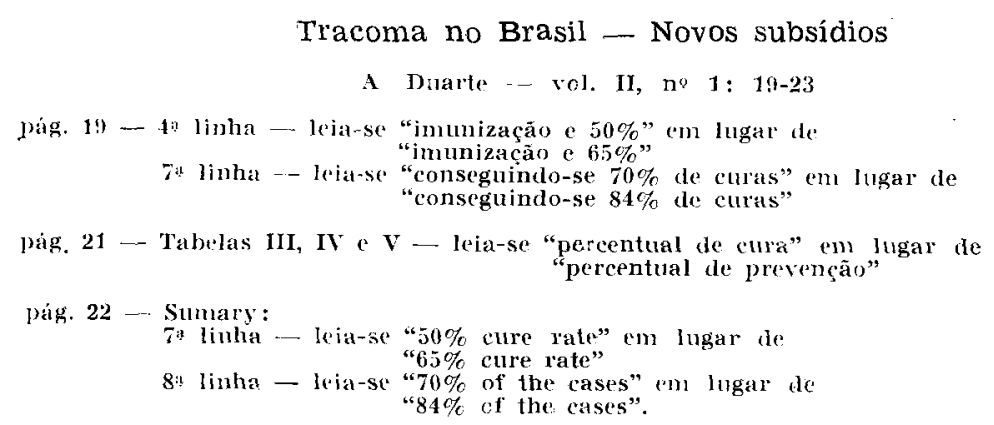

